\title{
THE DECISION OF SALT FARMERS BEHAVIOR TO THE USE GEOMEMBRANE TECHNOLOGY USING FUZZY AHP \\ (CASE In Lembung Village, Galis District, PAMEKASAN REgenCy)
}

\author{
Fitrotin Nazizah, Rosihan Asmara, Agustina Shinta Hartati Wahyuningtyas \\ Study Program of Agricultural Economy, Agriculture Faculty, University of Brawijaya \\ Jl. Veteran, Malang (0341) 565845 \\ *corresponding author: fitrotinnazizah@gmail.com
}

\begin{abstract}
Pamekasan regency is an area in Madura Island that has the potential to increase the quality and quantity of salt by recommending the use of geomembrane technology. This research will give recommendation of factor is the highest priority of salt farmer's behavior decisions on the use of geomembrane technology. The method developed in this research are combination of AHP and Fuzzy AHP method. AHP is used to determine the consistency of judgments made by each respondent and Fuzzy AHP is used to determine the criteria weight and subcriteria to determine the highest priority criteria and subcriteria decisions. Priority results using FAHP obtained that highest priority factor the behavior decisions of salt farmers towards the use of geomembrane technology at the level of farmers and agencies to technical aspects is production result subcriteria, to economic aspects is profit of salt farmers subcriteria, to socio cultural aspect is geomembrane technology is corresponding government advice and to environment aspects is quality of salt
\end{abstract}

Keywords: $A H P, F A H P$, and Salt

http://dx.doi.org/10.21776/ub.agrise.2020.020.4.4

Received 2 July 2020

Accepted 20 October 2020

Available online 30 October 2020

INTRODUCTION. The use of traditional technology in salt farming carried out in the past and continues to the present raises problems for salt farmers and government. one of the problems is the low quality of salt produced by farmers because of the use of traditional technology (Saragih, 2016). Based on this problems, so need a technology that can reduce problems related to the quality and production of salt, so that it can increase production and quality of salt and reduce import of salt in Indonesia. The technology that can improve the quality and quantity of salt is a geomembrane technology. (Effendy, Zainuri, \& Hafiluddin, 2011), the use of geomembrane technology can produce good quality salt, is a quality 1 which has a clear white color.

It is also listed in Community Salt Business Empowerment Program (PUGAR) which was announced by Ministry of Maritime Affairs and
Fisheries (KKP) in 2011-2012 an effort made by the government to meet national salt needs.(Mun'im, 2015). Where, one of the PUGAR programs given to farmers is using good technology, that is geomembrane in their farming.

Based on the problem, Lembung Village, Galis District, Pamekasan Regency is one area in Madura Island which has the potential to produce salt, but the use of geomembrane technology is low. This can happen because salt farmers still managed to use traditional methods which has been done for a long time and passed down from generation to generation, and the other hand if they switch to using geomembrane technology, then will add to costs and the results of salt quickly shrink (Abdullah \& Susandini, 2018).

Based on the case that occurred is the behavior of salt farmers to the use of geomembrane

CITATION: Nazizah, F., Asmara, R., Wahyuningtyas, A. (2020). The Decision of Salt Farmers Behavior to the Use Geomembrane Technology Using Fuzzy AHP (Case in Lembung Village, Galis District, Pamekasan Regency), Agricultural Socio-Economics Journal, 20(4), 291-298 DOI: http://dx.doi.org/10.21776/ub.agrise.2020.020.4.4 
technology is low, then need to know the factors that cause salt farmers reject and accept the innovation, and to know the most priority factor of salt farmers in deciding to use geomembrane technology in Lembung Village.

Although geomembrane technology has been used since 2014, but until now there are still salt farmers that use traditional methods so production of salt is low. Efforts to increase production not only requires cultivation techniques but also needs to be balanced with changes in the mindset and behavior of farmers. So that this problem can be solved by the method Multi Criteria Decision Making (MCDM).

AHP (Analytical Hierarchy Process) is one of the MCDM methods that is very good to combine opinions of experts. AHP performs pairwise comparisons of variables which is the determinant in the decision making process. However, AHP method not yet effectively used with a large number of criteria and subcriteria, so as to cover this weakness then another method of decision making is needed, namely the FAHP (Fuzzy Analytical Hierarchy Process) method. The workings of this method use the principle that defines pairing obtained in AHP used in this method which is then converted into the form of a TFN scale.

The purpose of the research is know the factors that are the highest priority on the decision of salt farmers' behavior towards the use of geomembrane technology.

Research Method. This research is located in Lembung Village, Galis District, Pamekasan Regency. Respondents in this study were from the level of farmers and agencies. The salt farmers sampled were 27 farmers. While agencies are 1 expert from fisheries department of Pamekasan district, 1 expert from Department of Industry of Pamekasan District, and 1 expert from academics who had done salt research in Pamekasan Regency. The method used to solve the problem is by combining AHP and Fuzzy AHP method. This research began with determine criteria and subcriteria which is considered the behavior of salt farmers to using geomembrane technology as Table 1.

Table 1. Determinants of Behavior of Salt Farmers to the Use of Geomembrane Technology

\begin{tabular}{|c|c|c|c|}
\hline NO & Criteria & Sucriteria & Sources \\
\hline 1 & C1 Technical & $\begin{array}{l}\text { C11 ease of use of geomembrane technology } \\
\text { C12 production result } \\
\text { C13 Geomembrane technology productivityIs higt }\end{array}$ & $\begin{array}{l}\text { (Istiana \& Deswati, 2014)), } \\
\text { Kholis (2017), Yanti (2014) } \\
\text { (Akmaluddin, Najamuddin, \& } \\
\text { Musbir, 2017) Silaban (2017), }\end{array}$ \\
\hline 2 & C2 Economy & $\begin{array}{l}\text { C21 buying ability } \\
\text { of salt farmers } \\
\text { C22 profit of salt farmers } \\
\text { C23 Production costs for salt farming }\end{array}$ & $\begin{array}{l}\text { Silaban (2017) } \\
\text { Silaban (2017), (Fachrista \& } \\
\text { Sarwendah, 2014) } \\
\text { (Ubando et al., 2014), } \\
\text { (Kusumo, Charina, Sadeli, \& } \\
\text { Mukti, 2017) }\end{array}$ \\
\hline 3 & $\begin{array}{l}\text { C3 Socio- } \\
\text { Cultural }\end{array}$ & $\begin{array}{l}\text { C31 Geomembrane technology is } \\
\text { corresponding } \\
\text { to the needs of salt farmers } \\
\text { C32 Geomembrane technology is } \\
\text { corresponding } \\
\text { government advice } \\
\text { C33 Geomembrane technology does not cause social } \\
\text { conflict } \\
\text { C34 total labor } \\
\text { C35 Geomembrane technology does not conflict with } \\
\text { local culture } \\
\text { C36 Geomembrane technology is in line with the } \\
\text { habits of salt farmers }\end{array}$ & $\begin{array}{l}\text { Istiana (2014), (Fachrista \& } \\
\text { Sarwendah, 2014 } \\
\text { (Silaban, Mustaruddin, \& } \\
\text { Soeboer, 2017) } \\
\text { (Kholis, Wahju, \& } \\
\text { Mustaruddin, 2017) } \\
\text { Akmaluddin (2017) }\end{array}$ \\
\hline 4 & $\begin{array}{l}\text { C4 } \\
\text { Environment }\end{array}$ & $\begin{array}{l}\text { C41 Selectivity of geomembrane technology } \\
\text { C42 Quality of salt }\end{array}$ & $\begin{array}{l}\text { (Mustaruddin, Baksoro, Kandi, } \\
\text { \& Nasruddin, 2017) }\end{array}$ \\
\hline
\end{tabular}


C43 Geomembran technology is environmentally

friendly

C44 Geomembrane technology is safe for salt farmers

Figure 1 explain the hierarchy of the process of evaluating the behavior of salt farmers the highest priority to using geomembrane technology. The AHP method used for rating the level of importance in each criterion and subcriteria, after the criteria and subcriteria rating values are obtained will be used as a reference as the determination of the pairing comparison matrix in AHP which will be changed to the TFN scale to determine the weights in the Fuzzy AHP method.

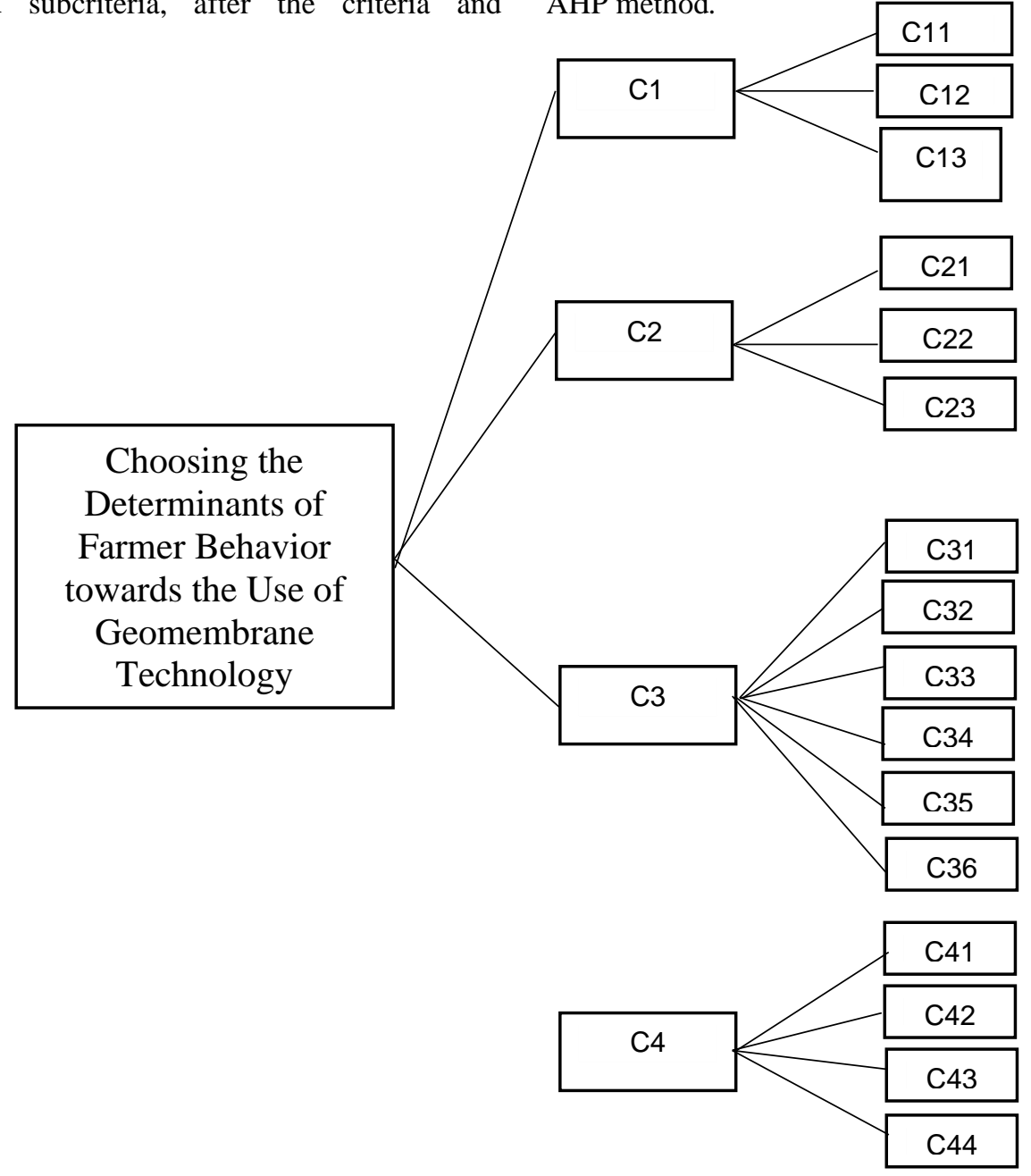

Figure 1. Hierarchy in AHP for Determining the Behavior Factors of Salt Farmers

Results and Discussion. Data collected consist of primary data and secondary data in a way: (1) use of questionnaires as a guide in conducting deep interviews with respondens about behavior of salt farmers to the use geomembrane technology, (2) field observation, (3) collection of information from relevant agencies, study of literature from research journals and reports related to research topics
Priority Factors at the Salt Farmer Level. Assesment which is conducted by salt farmers are to be consistent, because value $\mathrm{CR}<0.1$ that is equal to 0.09 . Weighting results with using fuzzy AHP can be seen to figure 1.2 below. Based on the figure can be known the weighting value which is obtained each criteria, that factor the highest priority decision behavior of salt farmers to the use geomembrane technology is shaded 
table that is economy aspects because has the highest weight value of 0.337 .

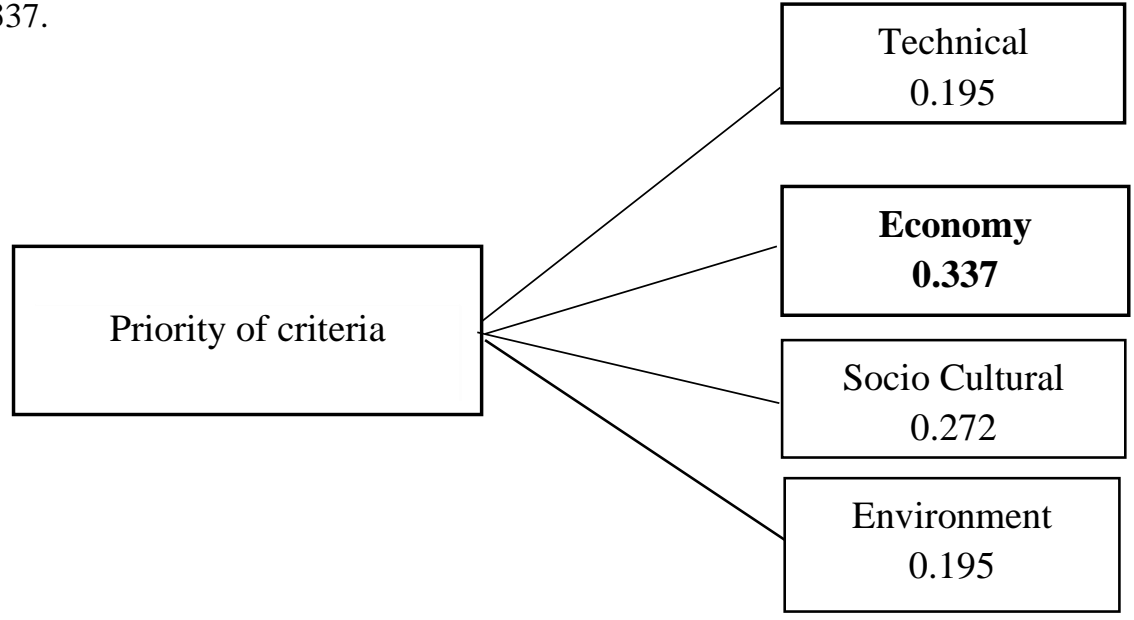

Figure 1.2. Factor Weighting Structure which is the Highest Priority

Technical aspects. Assesment which is conducted by salt farmers are to be consistent, because value CR < 0.1 that is equal to 0.024 . Weighting results with using fuzzy AHP can be seen to figure 1.3. Based on the figure can be known the weighting value which is obtained each subcriteria, that factor the highest priority decision behavior of salt farmers to the use geomembrane technology is shaded table that is production result because has the highest weight value of 0.470 .

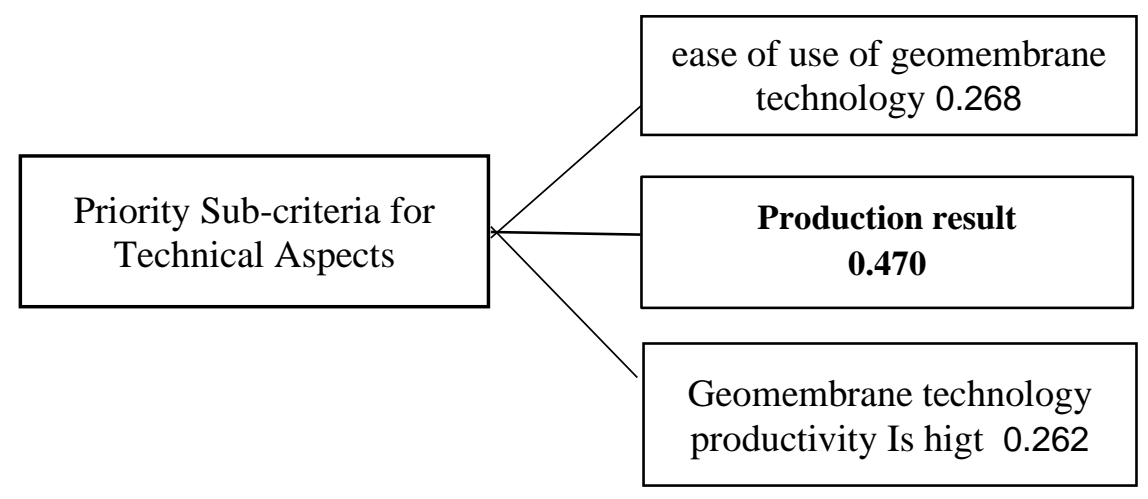

Figure 1.3. Sub-criteria priority weighting structure technical aspects at the farmer level

Economy aspects. Assesment which is conducted by salt farmers are to be consistent, because value CR < 0.1 that is equal to 0.098 . Weighting results with using fuzzy AHP can be seen to figure 1.4. Based on the figure can be known the weighting value which is obtained each subcriteria, that factor the highest priority decision behavior of salt farmers to the use geomembrane technology is shaded table that is profit of salt farmers because has the highest weight value of 0.495

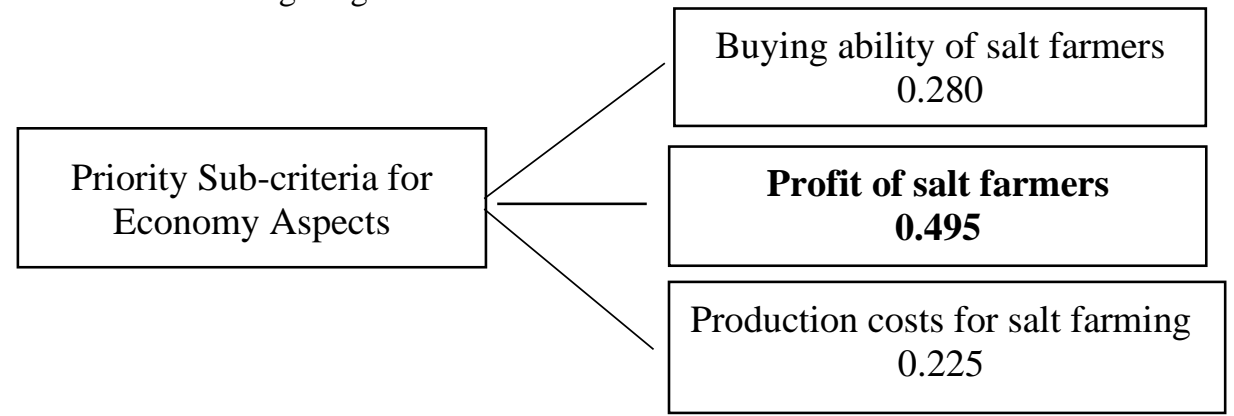

Figure 1.4. Sub-criteria priority weighting structure economy aspects at the farmer level 
Socio cultural aspects. Assesment which is conducted by salt farmers are to be consistent, because value CR $<0.1$ that is equal to 0.095 . Weighting results with using fuzzy AHP can be seen to figure 1.5. Based on the figure can be known the weighting value which is obtained each subcriteria, that factor the highest priority decision behavior of salt farmers to the use geomembrane technology is shaded table that is Geomembrane technology is corresponding government advice because has the highest weight value of 0.252 .

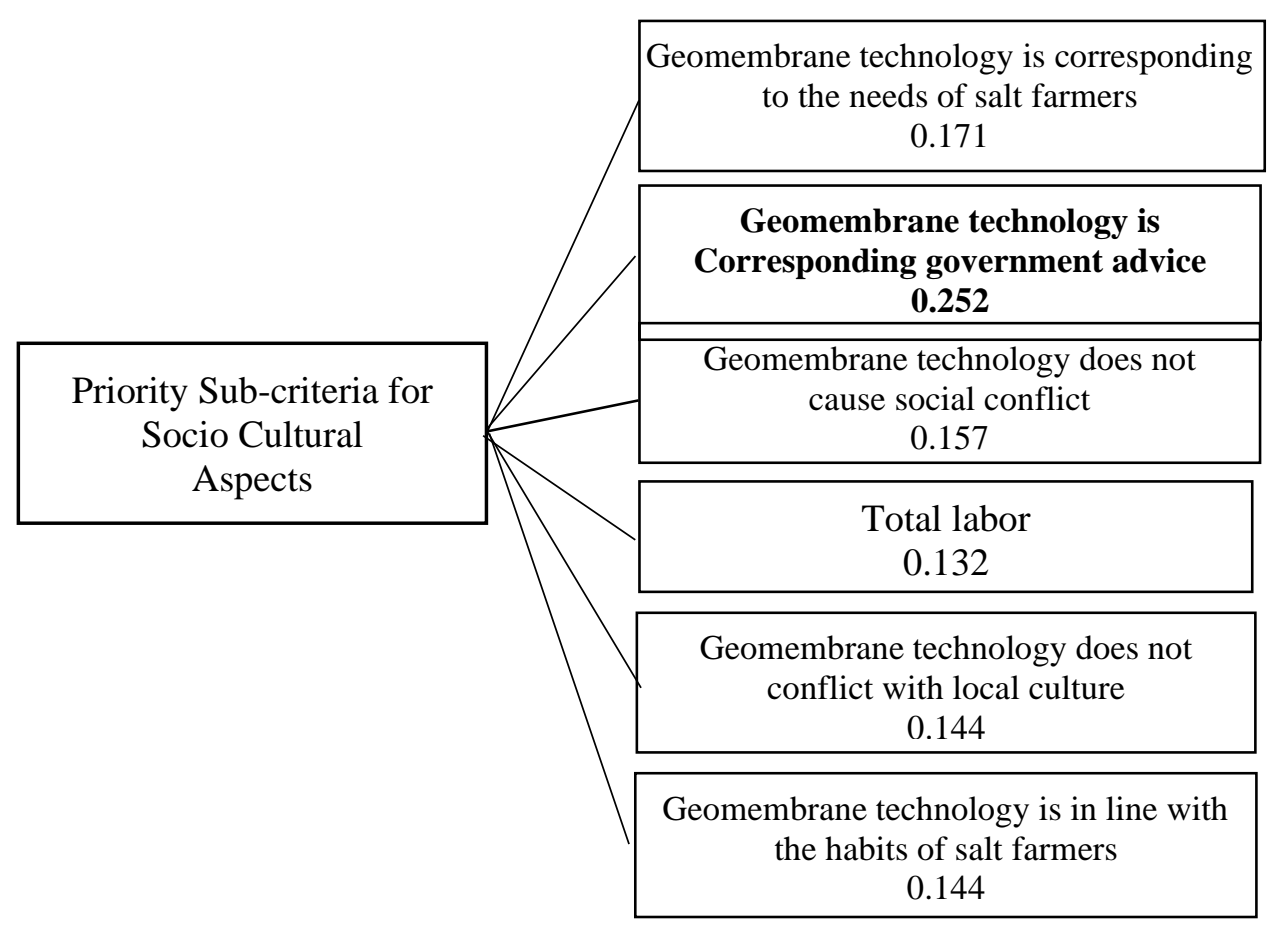

Figure 1.5. Sub-criteria priority weighting structure socio cultural aspects at the farmer level

Environment aspects. Assesment which is conducted by salt farmers are to be consistent, because value $\mathrm{CR}$ $<0.1$ that is equal to 0.08 .. Weighting results with using fuzzy AHP can be seen to figure 1.6. Based on the figure can be known the weighting value which is obtained each subcriteria, that factor the highest priority decision behavior of salt farmers to the use geomembrane technology is shaded table that is quality of salt because has the highest weight value of 0.389 .

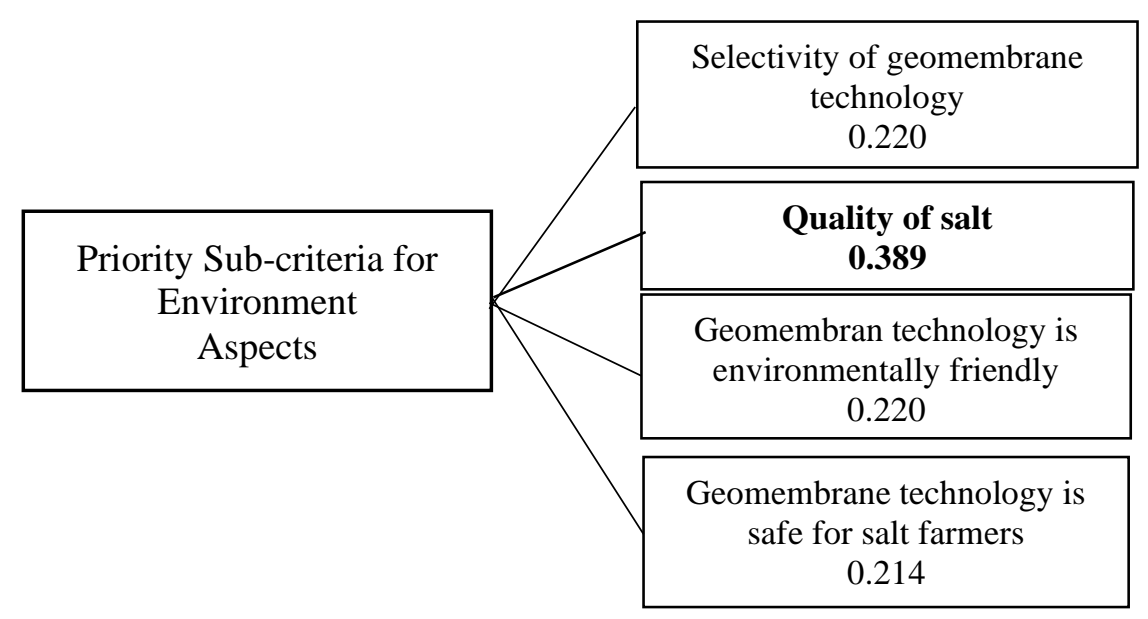

Figure 1.6. Sub-criteria priority weighting structure environment aspects at the farmer level 
Factors at the Institution Level. Assesment which is conducted by instituation are to be consistent, because value $\mathrm{CR}<0.1$ that is equal to 0.05 . Weighting results with using fuzzy AHP can be seen to figure 1.7. Based on the figure can be known the weighting value which is obtained each criteria, that factor the highest priority decision behavior of salt farmers to the use geomembrane technology is shaded table that is economy aspect because has the highest weight value of 0.326 .

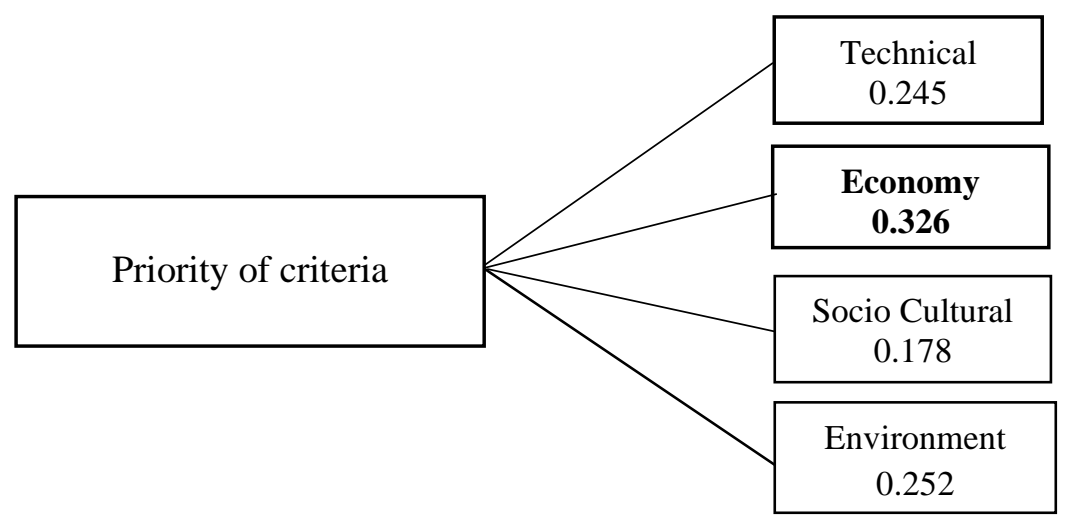

Figure 1.7. Factor Weighting Structure which is the Highest Priority

Technical aspects. Based on the results of the research that value of $\mathrm{CR}$ is equal to $0.003(\mathrm{CR}<0.1)$. this means that assessment carried out by institution to technical aspect subcriteria is consistent.

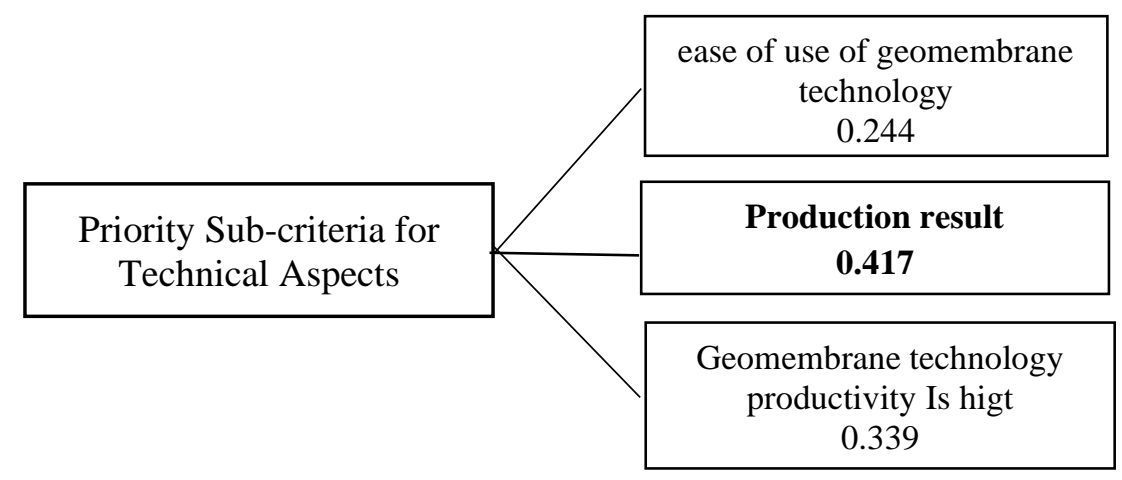

Figure 1.8. Sub-criteria priority weighting structure technical aspects at the institution level

Results of analysis on technical aspects using fuzzy AHP can be seen to figure 1.8. Based on the figure can be known that subcriteria of production results is a subcriteria that has the highest weight value is equal 0.417 .

Economy aspects. Based on the results of the research that value of $\mathrm{CR}$ is equal to $0.016(\mathrm{CR}<0.1)$, this means that assessment carried out by institution to economy aspect subcriteria is consistent. Results of analysis on economy aspects using fuzzy AHP can be seen to figure 1.9. Based on the figure can be known that subcriteria of profit of salt farmers is a subcriteria that has the highest weight value is equal to 0.433 .

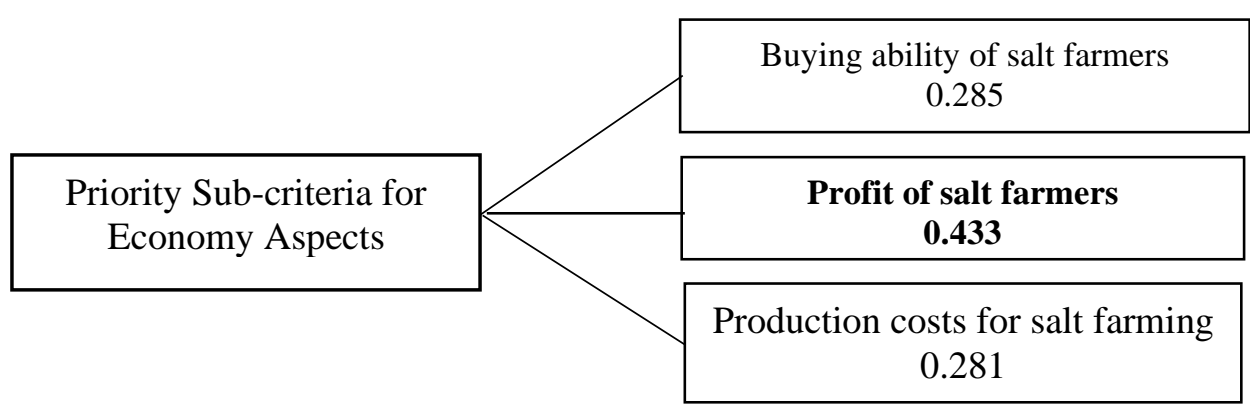

Figure 1.9. Sub-criteria priority weighting structure economy aspects at the institution level 
Socio cultural aspect Based on the results of the research that value of $\mathrm{CR}$ is equal to $0.067(\mathrm{CR}<0.1)$, this means that assessment carried out by institution to socio cultural aspect subcriteria is consistent. Results of analysis on socio cultural aspects using fuzzy AHP

can be seen to figure 1.10. Based on the figure can be known that subcriteria of Geomembrane technology iscorresponding government advice is a subcriteria that has the highest weight value is equal to 0.233 . corresponding to the needs of salt farmers 0.159

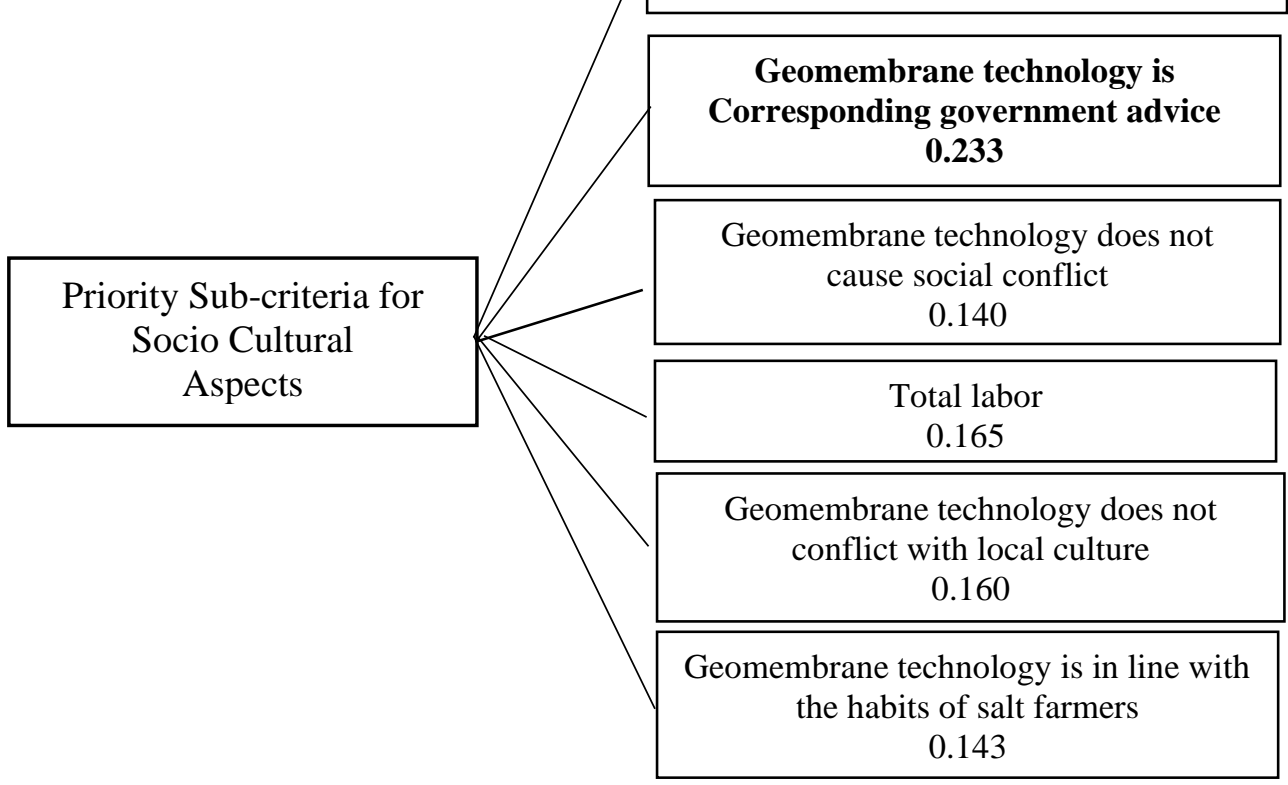

Figure 1.10. Sub-criteria priority weighting structure socio cultural aspects at the institution level

Environment aspect. Based on the results of the research that value of $\mathrm{CR}$ is equal to $0.04(\mathrm{CR}<0.1)$, this means that assessment carried out by institution to environment aspect subcriteria is consistent. Results of analysis on environment aspects using fuzzy AHP can be seen to figure 1.11. Based on the figure can be known that subcriteria of is a subcriteria that has the highest weight value is equal to 0.309 .

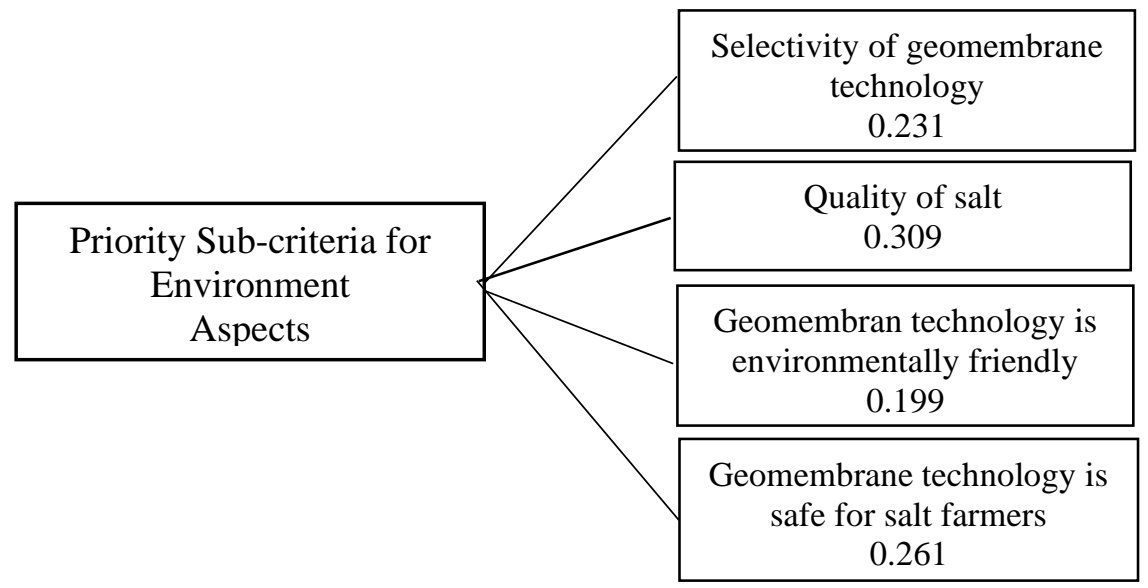

Figure 1.11. Sub-criteria priority weighting structure environment aspects at the institution level

Conclusions. The application of AHP and fuzzy AHP methods in determining the behavior of salt farmers the highest priority to the use of geomembrane technology in Lembung Village, 
Galis District, Pamekasan Regency can help provide the best alternative recommendations for decision makers. The MCDM method with the combination of AHP and fuzzy AHP is sufficient to be used for the determining the behavior of salt farmers the highest priority to the use of geomembrane technology in Lembung Village. AHP is used to determine pairwise comparison matrices from criteria and subcriteria and assess the consistency of the assessment of each respondent. Then do the ranking to criteria and subcriteria with using fuzzy AHP method. The result of the using fuzzy AHP method obtained by that highest priority factor the behavior decisions of salt farmers towards the use of geomembrane technology at the level of farmers and agencies to technical aspects is production result subcriteria, to economic aspects is profit of salt farmers subcriteria, to socio cultural aspect is geomembrane technology is corresponding government advice and to environment aspects is quality of salt. The result of the implementation of AHP and fuzzy AHP methods will be taken into consideration for decision makers to salt farmers and local government to develop the use geomembrane technology in accordance with existing aspects.

\section{REFERENCES}

Abdullah, Z. A., \& Susandini, A. (2018). MEDIA PRODUKSI (GEOMEMBRANE) DAPAT MENINGKATKAN KUALITAS DAN HARGA JUAL GARAM (STUDY KASUS : LADANG GARAM MILIK RAKYAT DI WILAYAH MADURA). Eco-Entrepreneurship, 3(2), 21-36.

Akmaluddin, Najamuddin, \& Musbir. (2017). Kinerja Alat Tangkap Ikan Cakalang Di Teluk Bone Kabupaten Luwu. Jurnal Balik Diwa, 8(1), 2935 .

Effendy, M., Zainuri, M., \& Hafiluddin. (2011). Intensifikasi lahan garam rakyat di kabupaten sumenep.
Fachrista, I. A., \& Sarwendah, M. (2014). Persepsi dan Tingkat Adopsi Petani Terhadap Inovasi Teknologi Pengelolaan Tanaman Terpadu Padi Sawah. Agriekonomika, 3(1), 1-10.

Istiana, \& Deswati, R. H. (2014). Persepsi Pembudidaya Terhadap Pengenalan Teknologi Pembuatan Pakan Ikan Berbahan Baku Lokal di Kecamatan Paciran, Kabupaten Lamongan. Seminar Nasional Kelautan IX, (April), 1-126.

Kholis, M. N., Wahju, R. I., \& Mustaruddin. (2017). Seleksi Unit Teknologi Penangkapan Ikan Kurau Eleutheronema Tetradactylum yang Unggulan dan Berkelanjutan. 9(2), 521-536.

Kusumo, R. A. B., Charina, A., Sadeli, A. H., \& Mukti, G. W. (2017). Persepsi Petani terhadap Teknologi Budidaya Sayuran Orhanik di Kabupaten Bandung Barat. Paspalum, 5(2), 1928.

Mun'im, A. (2015). ANALISIS USAHA PETAMBAK GARAM DAN PERANANNYA DALAM PEREKONOMIAN TAHUN 2012 ( Studi Kasus Petambak Garam PUGAR). Sosek KP, 10(2), 217-228.

Mustaruddin, Baksoro, M. S., Kandi, O., \& Nasruddin. (2017). Environmental and Technical Approach In the Selection of Fishing Gear Featured in WPP 571 Aceh. International Journal of Sciences: Basic and Applied Research, 31(3), 44-53.

Saragih, H. R. (2016). PENDAPATAN PETAMBAK DAN FAKTOR-FAKTOR YANG MEMPENGARUHI PRODUKSI GARAM (Desa Muara Baru, Cilamaya Wetan, Karawang).

Silaban, J., Mustaruddin, \& Soeboer, D. A. (2017). Determination of Best Fishing Gear for Small Pelagic Fisheries at Palabuhanratu Sukabumi. Albacore, I(2), 225-234.

Ubando, A. T., Cuello, J. L., Culaba, A. B., Angelo, M., Promentilla, B., \& Tan, R. R. (2014). MultiCriterion Evaluation of Cultivation Systems for Sustainable Algal Biofuel Production using Analytic Hierarchy Process and Monte Carlo Simulation. Energy Procedia, 61, 389-392. https://doi.org/10.1016/j.egypro.2014.11.1132 